\title{
Efektivitas Pengolahan Limbah Domestik di Instalasi Pengolahan Air Limbah (IPAL) Suwung-Denpasar, Bali
}

\author{
Desak Made Goldyna Rarasari a*, I Wayan Restu a, Ni Made Ernawati a \\ a Program Studi Manajemen Sumberdaya Perairan, Fakultas Kelautan dan Perikanan, Universitas Udayana, Jimbaran, Badung, Bali - Indonesia \\ * Penulis koresponden. Tel.: +62-857-372-340-03 \\ Alamat e-mail: goldynararasari@gmail.com
}

Diterima (received) 9 November 2017; disetujui (accepted) 10 Oktober 2018; tersedia secara online (available online) 12 Oktober 2018

\begin{abstract}
Denpasar City and Badung Regency has a very large population growth rate, diversity, and intensity of development activities that produced domestic waste which if not properly managed, causes burden and damage to the aquatic environment. Wastewater Treatment Plant (WWTP) Suwung-Denpasar is one of the wastewater treatment business for waste management center from the area around Denpasar, Sanur, and Kuta. Based on the data analysis was known that the waste generated has not been appropriate environmental quality standards so that will affect the quality of the water. The aim of his research is to investigate the effectiveness of domestic wastewater treatment conducted in March - April 2017 by observation method in process and effectiveness measurement of waste water treatment. The processing begins with the distribution of waste in Denpasar and Sanur areas that are channeled to the bar screen and then collected to the inflow pumping station to be channeled to the receiving tank including waste from the Kuta area. Subsequent waste flows into the chamber grit to be filtered and taken to the aeration pond for 2 days then to the sedimentation pool for 16 hours and flowed to the effluent canal. The results showed the percentage of effective waste treatment in oil and fat restoration $85 \%$, detergent $62 \%$, and BOD $57 \%$, while not effective in ammonia change because only reduced $26 \%, \mathrm{DO}$ and $\mathrm{H}_{2} \mathrm{~S}$ are not in accordance with environmental quality standards.
\end{abstract}

Keywords: effectiveness; domestic waste; WWTP Suwung-Denpasar; water quality

\begin{abstract}
Abstrak
Kota Denpasar dan Kabupaten Badung memiliki laju pertumbuhan penduduk, diversitas, dan intensitas kegiatan pembangunan yang menghasilkan limbah domestik yang apabila tidak dikelola secara baik menyebabkan beban dan kerusakan lingkungan perairan. Instalasi Pengolahan Air Limbah (IPAL) Suwung-Denpasar merupakan salah satu usaha pengolahan air limbah untuk pusat pengelolaan limbah dari daerah sekitar Denpasar, Sanur, dan Kuta. Berdasarkan data analisis diketahui bahwa limbah yang dihasilkan belum sesuai baku mutu lingkungan sehingga akan berpengaruh terhadap kualitas perairan. Penelitian ini bertujuan untuk mengetahui tingkat efektivitas pengolahan air limbah domestik yang dilaksanakan bulan Maret - April 2017 dengan metode observasi pada proses dan pengukuran efektivitas pengolahan air limbah. Proses pengolahan dimulai dari penyaluran limbah yang berada di wilayah Denpasar dan Sanur yang dialirkan ke bar screen dan selanjutnya ditampung ke inflow pumping station untuk disalurkan ke receiving tank termasuk limbah dari daerah Kuta. Limbah selanjutnya mengalir ke grit chamber untuk disaring dan dibawa ke kolam aerasi selama 2 hari kemudian ke kolam sedimentasi selama 16 jam dan dialirkan ke kanal effluent. Hasil penelitian menunjukkan persentase pengolahan limbah efektif dalam perbaikan minyak dan lemak $85 \%$, deterjen $62 \%$, dan BOD $57 \%$, sedangkan tidak efektif dalam perubahan amoniak karena hanya berkurang $26 \%$, DO dan $\mathrm{H}_{2} \mathrm{~S}$ yang tidak sesuai dengan baku mutu lingkungan.
\end{abstract}

Kata Kunci: efektivitas; limbah domestik; IPAL; kualitas perairan 


\section{Pendahuluan}

Kota Denpasar dan Kabupaten Badung memiliki laju pertumbuhan penduduk yang sangat besar dalam tahun 2015-2020 yaitu sebesar 1,8 dan 2,08. Selain itu tingkat kepadatan penduduk di 2 Kabupaten/Kota tersebut juga pesat dengan luas wilayah Kota Denpasar 127,78 $\mathrm{km}^{2}$ mencapai 6891,5 penduduk $/ \mathrm{km}^{2}$ pada tahun 2015. Sedangkan Kabupaten Badung dengan luas wilayah 418,52 $\mathrm{km}^{2}$ mencapai 1472,8 penduduk $/ \mathrm{km}^{2}$ pada tahun yang sama (BPS, 2016). Hal tersebut berpengaruh pada luas lahan yang tetap sehingga mengakibatkan tekanan terhadap lingkungan yang semakin berat.

Meningkatnya aktivitas manusia, perubahan guna lahan dan semakin beragamnya pola hidup masyarakat perkotaan yang menghasilkan limbah domestik menjadikan bahan pencemar yang semakin besar dari waktu ke waktu. Bahan pencemar tersebut dapat berupa pencemar kimiawi yang berasal dari zat-zat kimia, pencemar fisik yang merupakan zat cair, padat, atau gas, pencemar biologis dari berbagai macam mikroorganisme penyebab penyakit, dan pencemar sosial dari perilaku yang tidak sesuai dengan norma sosial. Akibat dari pembuangan limbah yang tidak terkendali dari aktivitas pembangunan menyebabkan penurunan kualitas perairan.

Air limbah domestik yang langsung dibuang ke dalam ekosistem perairan umumnya akan mempengaruhi air yang ada pada ekosistem penerimanya, bahkan pada akhirnya akan berakibat pada berubahnya komposisi kandungan zat yang ada di dalamnya atau dengan kata lain akan mengakibatkan terjadinya pencemaran pada ekosistem perairan penerimanya (Cordova, 2008). Limbah dalam jangka panjang atau jangka pendek akan membuat perubahan terhadap lingkungan sehingga perlu diupayakan suatu pengolahan limbah sesuai dengan karakter limbah itu sendiri (Ginting, 2007).

Instalasi Pengolahan Air Limbah (IPAL) Suwung-Denpasar merupakan salah satu usaha pengolahan air limbah yang dibangun guna mengolah limbah rumah tangga yang dipusatkan pada daerah sekitar Denpasar, Sanur, dan Kuta dengan pembangunan Denpasar Sewerage Development Project (DSDP). Pengolahan air limbah pada IPAL Suwung tersebut dilakukan secara biologis dengan menggunakan sistem lagoon (BLUPAL, 2007). Air limbah yang telah diolah kemudian dialirkan melalui saluran air (badan air) menuju ke hutan mangrove (BLUPAL, 2007).

Berdasarkan data analisis terhadap air limbah pada IPAL Suwung diketahui bahwa kualitas air effluent (buangan) yang dihasilkan masih belum sesuai dengan baku mutu yang diharapkan (Sulihiningtyas dkk., 2010). Namun penelitian yang meninjau tentang tingkat efektivitas pengolahan limbah IPAL sesuai baku mutu lingkungan yang sudah ditetapkan belum pernah dilakukan. Sehingga penelitian mengenai tingkat efektivitas pengolahan air limbah domestik pada pembangunan DSDP di IPAL Suwung penting dilakukan untuk perbaikan sistem IPAL selanjutnya yang berpengaruh pada sumber daya perairan yang berada disekitar kawasan tersebut.

\section{Metode Penelitian}

\subsection{Waktu dan Lokasi Penelitian}

Penelitian dilakukan selama 2 bulan yaitu Bulan Maret - April 2017. Tempat pengambilan sampel air limbah pada IPAL Suwung Denpasar dilakukan pada enam lokasi yaitu influent/receiving tank (T1), kolam aerasi 1 (T2), kolam aerasi 2 (T3), kolam sedimentasi 1 (T4), kolam sedimentasi 2 (T5), effluent (T6) (Gambar 1).

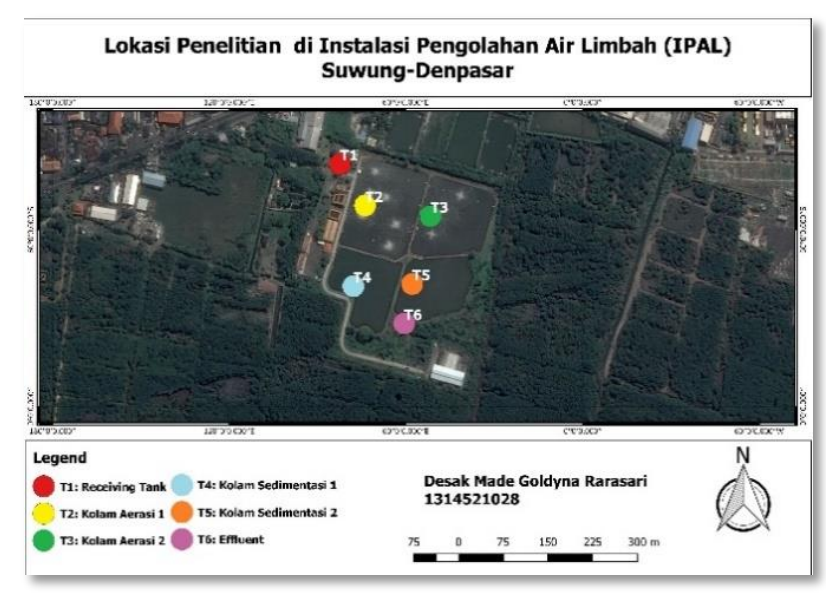

Gambar 1. Peta Lokasi Penelitian

\subsection{Alat dan Bahan}

Alat dan bahan yang digunakan dalam penelitian meliputi alat dan bahan yang digunakan dalam 
pengambilan sampel air dan pengukuran kualitas air secara insitu. Beberapa alat dan bahan tersebut disajikan dalam Tabel 1.

Tabel 1

Alat Dan Bahan

\begin{tabular}{clll}
\hline No. & Parameter & \multicolumn{1}{c}{ Alat } & Bahan \\
\hline 1. & $\begin{array}{l}\text { Titik } \\
\text { koordinat } \\
\text { lokasi }\end{array}$ & GPS & \\
2. & Sampel air & $\begin{array}{l}\text {-Water } \\
\text { sampler } \\
\end{array}$ & \\
& & -Botol sampel & \\
& & -Kertas label & \\
3. & Suhu & Termometer & Sampel air \\
4. & DO & DO meter & Sampel air \\
5. & pH & pH meter & Sampel air \\
7. & Sterilisasi alat & Tisu & Aquades \\
\hline
\end{tabular}

\subsection{Metode Penelitian}

Penelitian ini menggunakan metode observasi pada proses pengolahan air limbah di IPAL dan pengkukuran efektivitas pengolahan air limbah. Penentuan lokasi penelitian menggunakan metode Purposive Sampling yaitu penentuan sampel (daerah penelitian) berdasarkan pertimbanganpertimbangan tertentu yaitu karakteristik bahan baku limbah yang masuk ke IPAL, efektivitas pada tiap proses pengolahan air limbah, dan hasil setelah proses pengolahan limbah tersebut berjalan. Pengambilan sampel dilakukan sebanyak 3 kali yaitu awal Bulan Maret, akhir Bulan Maret, dan awal Bulan April. Waktu pengambilan sampel disesuaikan dengan waktu tinggal air limbah pada IPAL Suwung Denpasar yaitu selama 2 hari pada kolam aerasi dan 16 jam pada kolam sedimentasi.

\subsubsection{Teknik Pengambilan Data}

Data yang diambil dalam penelitian ini meliputi data primer dan data sekunder. Data primer meliputi sampel air influent, effluent, pertemuan effluent dengan badan perairan, dan kontrol yang meliputi suhu, $\mathrm{pH}, \mathrm{DO}, \mathrm{BOD}$, minyak dan lemak, zat padat tersuspensi (TSS), Amoniak $\left(\mathrm{NH}_{3}\right)$, Surfaktan (deterjen), dan Hidrogen Sulfida $\left(\mathrm{H}_{2} \mathrm{~S}\right)$. Data primer sampel terdiri dari data yang diambil secara insitu dan eksitu. Sampel diambil secara langsung sebagai sampel uji BOD, minyak dan lemak, TSS, amoniak, surfaktan, dan hidrogen sulfida. Pengambilan sampel air dilakukan dengan menggunakan alat water sampler pada tiap titik dan dimasukkan ke dalam botol sampel. Parameter suhu, $\mathrm{pH}$, dan $\mathrm{DO}$ dilakukan pengukuran secara langsung (insitu).

\subsection{Analisis Data}

Analisis data dalam penelitian ini dilakukan melalui tiga pendekatan, yaitu pendekatan analisis deskriptif, analisis komperatif, dan analisis beban pencemar. Analisis deskriptif dengan mengklasifikasikan data menjadi dua kelompok yaitu data kualitatif dan kuantitatif. Analisis komperatif dengan membandingkan hasil dengan baku mutu, dan pendekatan dengan analisis beban pencemaran berdasarkan Peraturan Menteri Lingkungan Hidup No. 5 Tahun 2014 tentang Baku Mutu Air Limbah untuk cara perhitungan debit limbah cair maksimum dan beban pencemaran maksimum (2).

Analisis persentase pengolahan IPAL SuwungDenpasar dievaluasi berdasarkan persen (\%) dengan rumus (Soeparman dan Suparmin, 2001)

$\%=\frac{p \cdot \text { influent }-p . \text { effluent }}{\text { parameter influent }} \times 100$

dimana p.influent adalah parameter pada air masukan limbah atau limbah di T1; dan p.effluent adalah hasil olahan limbah pada T6.

$\mathrm{BPA}=(\mathrm{CA}) \mathrm{j} \times \mathrm{DA}$

dimana $B P A$ adalah beban pencemaran sebenarnya; $(C A) j$ adalah kadar sebenarnya unsur $j$ $(\mathrm{mg} / \mathrm{l})$; dan $D A$ adalah hasil pengukuran debit limbah cair, dinyatakan dalam $\mathrm{m}^{3} /$ hari.

\section{Hasil}

\subsection{Proses Pengolahan IPAL Suwung-Denpasar, Bali}

Instalasi Pengolahan Air Limbah (IPAL) adalah bagian dari Denpasar Sewerage Development Project (DSDP) yang merupakan proyek pembangunan sistem perpipaan air limbah terpusat yang mencakup Kota Denpasar dan Kabupaten Badung. Sistem secara terpusat (off-site) dilakukan dengan mengumpulkan semua limbah dari rumah tangga dan sejenisnya dan disalurkan melalui jaringan pipa ke IPAL Suwung untuk diolah terlebih dahulu sebelum dibuang ke sungai atau laut sesuai baku mutu yang berlaku. Pemilihan wilayah Sanur, Kuta, dan Denpasar sebagai tujuan 
pembangunan DSDP karena wilayah Sanur dan Kuta merupakan area destinasi pariwisata internasional yang banyak diminati oleh wisatawan. Sedangkan Denpasar merupakan pusat kota dan pusat pemerintahan di Bali sehingga sanitasi menjadi salah satu isu utama yang harus diperhatikan dengan serius. Berikut merupakan data area pelayanan dari DSDP tahap I dan II (Tabel 2 dan 3).

Tabel 2

Area Pelayanan DSDP I.

\begin{tabular}{lccc}
\hline $\begin{array}{c}\text { Area } \\
\text { Pelayanan }\end{array}$ & $\begin{array}{c}\text { Luas Area } \\
\text { Pelayanan } \\
\text { (HA) }\end{array}$ & $\begin{array}{c}\text { Target } \\
\text { Pelanggan } \\
\text { (SR) }\end{array}$ & $\begin{array}{c}\text { Penduduk } \\
\text { Terlayani }\end{array}$ \\
\hline Denpasar & 520 & 5.350 & 73.700 \\
Sanur & 330 & 1.890 & 16.500 \\
Kuta & 295 & 1.860 & 13.000 \\
\hline
\end{tabular}

Sumber: Aviananda, 2014

Tabel 3

Area Pelayanan DSDP II.

\begin{tabular}{lccc}
\hline $\begin{array}{c}\text { Area } \\
\text { Pelayanan }\end{array}$ & $\begin{array}{c}\text { Luas Area } \\
\text { Pelayanan } \\
\text { (HA) }\end{array}$ & $\begin{array}{c}\text { Target } \\
\text { Pelanggan } \\
\text { (SR) }\end{array}$ & $\begin{array}{c}\text { Penduduk } \\
\text { Terlayani }\end{array}$ \\
\hline Denpasar & 280 & 3.800 & 33.000 \\
Sanur & 160 & 900 & 5.300 \\
Kuta & 365 & 2.500 & 12.300 \\
\hline
\end{tabular}

Sumber: Aviananda, 2014

Penyaluran air limbah yang masuk dari Sanur dan Kuta akan dipompa melalui stasiun pompa. Kapasitas pompa di Sanur adalah 12,4 m³/menit dengan 3 pompa. Sedangkan kapasitas di Kuta sebesar 23,8 $\mathrm{m}^{3} /$ menit dengan 3 pompa dan bar screen yang menyaring sampah pada aliran limbah. Sedangkan limbah dari Denpasar tidak memerlukan saluran pompa karena penyaluran tersebut sepenuhnya dilakukan dengan sistem gravitasi.

Limbah Denpasar dan Sanur akan bertemu di perempatan Benoa lalu di pompa dengan pompa kecil yang disebut wet pit. Limbah yang terdapat pada wet pit dialirkan ke bar screen yang berfungsi untuk mengurangi atau menghilangkan/menahan padatan kasar seperti sampah plastik, kayu, dan lainnya. Screen pada bar memiliki alat dengan bukaan atau spasi sekitar $2 \mathrm{~cm}$ antar bar yang berukuran $1 \mathrm{~cm}$.

Limbah cair yang sudah melewati bar screen akan ditampung ke inflow pumping station yang merupakan sumur dipermukaan yang mengalirkan air limbah dengan bantuan pompa dengan kapasitas $15,5 \mathrm{~m}^{3} /$ menit, tegangan $45 \mathrm{kw}$, rpm 990/menit, daya $45 \mathrm{kw}$, dan kemampuan menarik 10 meter. Inflow pumping station berfungsi untuk menyalurkan limbah ke receiving tank yang letaknya lebih tinggi daripada masukan limbah. Receiving tank merupakan tempat berkumpulnya limbah sementara sebelum di distribusikan ke pengolahan yang selanjutnya agar dapat menstabilkan variasi debit. Limbah tersebut selanjutnya mengalir ke grit chamber untuk menghilangkan tanah kasar, pasir, dan partikel halus dari air limbah dengan bantuan blower. Limbah yang sudah tersaring selanjutnya dibawa ke kolam aerasi.

IPAL memiliki 2 kolam aerasi dengan volume masing-masing $52.889 \mathrm{~m}^{3}$ dan $42.169 \mathrm{~m}^{3}$ dan keduanya memiliki kedalaman sekitar 4 meter dengan menggunakan 21 aerator mekanik berupa surface aerator untuk membantu mekanisasi pasokan oksigen terlarut di dalam air. Namun sampai saat ini terdapat 10 aerator yang rusak karena kurangnya penyaringan sampah, sehingga menghambat kinerja yang mengakibatkan konslet. Limbah akan mengalami proses selama dua hari dan selanjutnya akan mengalir ke kolam sedimentasi.

Kolam sedimentasi terdiri dari 2 kolam yang merupakan lanjutan dari masing-masing kolam aerasi dengan volume $24.371 \mathrm{~m}^{3}$ dan $24.273 \mathrm{~m}^{3}$ yang memiliki kedalaman $1,7 \mathrm{~m}$ dan ruang lumpur $0,7 \mathrm{~m}$. Fungsi dari kolam sedimentasi adalah untuk memisahkan air limbah dengan padatan larutan total (TSS) yang berlangsung sekitar 16 jam. Kolam aerasi dan kolam sedimentasi dilapisi geomembrane dan geotextile untuk menghindari rembesan air limbah keluar dari kolam. Air dari proses sedimentasi akan dialirkan ke kanal effluent yang merupakan saluran air hasil pengolahan yang menuju badan perairan.

\subsection{Efektivitas Pengolahan Limbah Cair Domestik di IPAL}

Efektivitas pengolahan air limbah domestik di IPAL dalam penelitian ini dapat dilihat melalui beberapa parameter kualitas air sesuai dengan Baku Mutu Air Limbah dan Baku Mutu Air Laut untuk Biota Laut. Dari hasil perhitungan influent dan effluent air limbah diperolehlah tingkat efektivitas dari proses pengolahan di IPAL (Tabel 
Tabel 4

Efektivitas Pengolahan Air Limbah Domestik di IPAL

\begin{tabular}{|c|c|c|c|c|c|c|}
\hline Parameter & $\begin{array}{c}\text { Rata-Rata } \\
\text { Influent (T1) }\end{array}$ & $\begin{array}{c}\text { Rata-Rata } \\
\text { Effluent (T6) }\end{array}$ & $\begin{array}{c}\text { Baku } \\
\text { Mutu I }\end{array}$ & $\begin{array}{c}\text { Baku } \\
\text { Mutu II }\end{array}$ & $\begin{array}{l}\text { Persentase } \\
\text { Efektivitas }\end{array}$ & Efektivitas \\
\hline Suhu & 30.34 & 30.40 & & $28-32$ & $0 \% *$ & Efektif \\
\hline $\mathrm{pH}$ & 7.58 & 7.87 & $6-9$ & $7-8,5$ & $0 \% *$ & Efektif \\
\hline $\mathrm{DO}$ & 1.41 & 2.83 & & $>5$ & $0 \%$ & Tidak Efektif \\
\hline BOD & 169.83 & 73.02 & 100 & 20 & $57 \%$ & Efektif \\
\hline TSS & 93.00 & 68.40 & 100 & $\geq 80$ & $26 \%$ & Efektif \\
\hline $\begin{array}{c}\text { Minyak \& } \\
\text { Lemak }\end{array}$ & 0.65 & 0.05 & 10 & & $85 \%$ & Efektif \\
\hline Amoniak & 19.50 & 14.34 & & 0,3 & $26 \%$ & Tidak Efektif \\
\hline Deterjen & 0.34 & 0.13 & & 1 & $62 \%$ & Efektif \\
\hline Sulfida & 0.28 & 17.84 & & 0,01 & $0 \%$ & Tidak Efektif \\
\hline
\end{tabular}

Keterangan

* $\quad$ : Suhu dan pH efektif karena konstan dan sesuai dengan baku mutu

I : Baku Mutu Air Limbah Usaha dan/atau Kegiatan Domestik

II $\quad$ : Baku Mutu Air Laut untuk Biota Laut pada Mangrove

4). Tingkat efektivitas dari pengolahan limbah berbeda-beda, efektivitas pengolahan BOD berkisar antara $57 \%$, TSS $26 \%$, minyak dan lemak $85 \%$, amoniak $26 \%$, deterjen $62 \%$, sedangkan kandungan sulfida pada limbah masih belum terdegradasi secara efektif.

Selain melihat secara keseluruhan dari efektivitas pengolahan limbah di IPAL, data pendukung dari efektivitas tersebut adalah dari tingkat kualitas perairan di tiap titik. Parameter kualitas air tersebut yaitu parameter fisika dan kimia yang meliputi suhu, pH, DO, BOD, TSS, minyak dan lemak, amoniak, deterjen, dan hidrogen sulfida $\left(\mathrm{H}_{2} \mathrm{~S}\right)$. Selain itu data pendukung lain adalah tingkat beban pencemaran berdasarkan debit limbah cair.

\subsubsection{Suhu}

Dari data yang diperoleh rata-rata suhu berkisar antara $30-31^{\circ} \mathrm{C}$. Namun suhu di tiap titik sampel bersifat fluktuatif (Gambar 2). Hasil pengukuran suhu di IPAL menunjukkan bahwa masih sesuai dengan baku mutu Peraturan Gubernur Provinsi Bali No. 16 Tahun 2016, baku mutu air laut untuk biota laut di kawasan mangrove yaitu berkisar antara $28-32^{\circ} \mathrm{C}$.

\subsubsection{Derajat Keasaman $(\mathrm{pH})$}

Nilai pH di IPAL Suwung-Denpasar menunjukkan hasil yang fluktuatif namun masih dalam kisaran 7,5- 7,8 (Gambar 3). Hal tersebut menunjukkan bahwa nilai $\mathrm{pH}$ masih dalam ambang batas karena berdasarkan baku mutu air limbah bagi usaha dan/atau kegiatan domestik kadar paling tinggi $\mathrm{pH}$ antara 6-9. Sedangkan berdasarkan baku mutu air laut untuk biota laut, $\mathrm{pH}$ berkisar antara 7-8,5.

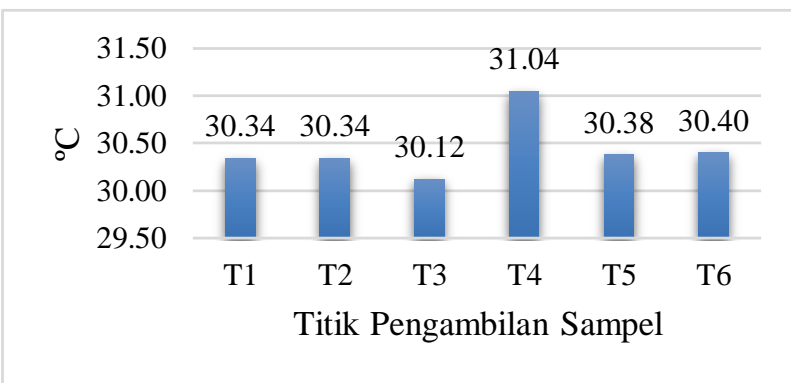

Gambar 2. Nilai Rata-Rata Suhu di Tiap Titik Sampel

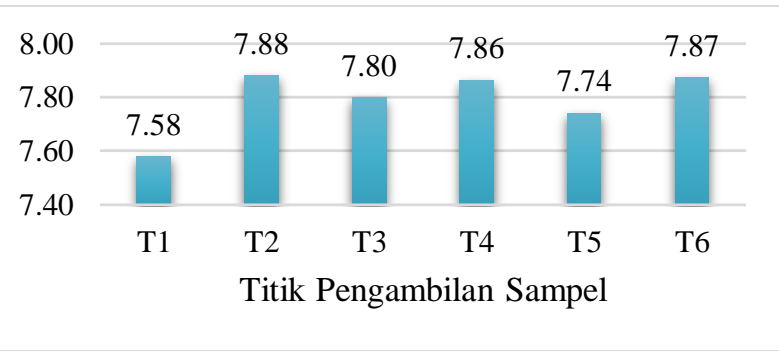

Gambar 3. Nilai Rata-Rata pH di Tiap Titik Sampel

\subsubsection{Oksigen Terlarut (DO)}

Kandungan oksigen terlarut dari hasil pengambilan data menunjukkan nilai yang fluktuatif di tiap titik sampel. Berdasarkan Peraturan Gubernur Provinsi Bali No. 16 Tahun 2016 baku mutu air laut untuk biota laut, kadar DO yang baik bagi perairan adalah $>5 \mathrm{mg} / \mathrm{l}$. Hal 
tersebut menunjukkan bahwa nilai DO di IPAL sangat rendah sehingga tidak sesuai dengan baku mutu (Gambar 4).

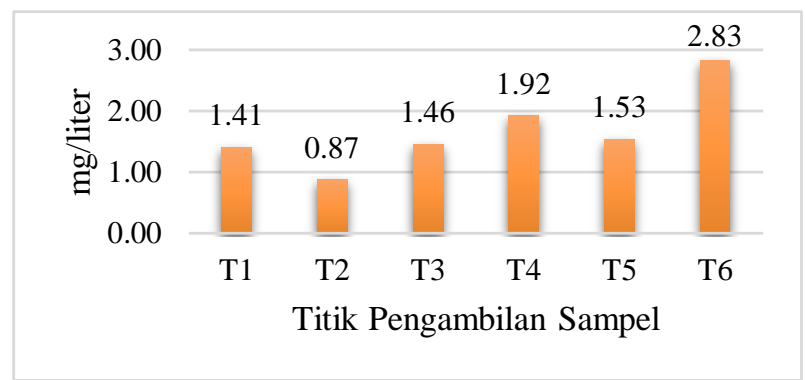

Gambar 4. Nilai Rata-Rata DO di Tiap Titik Sampel

\subsubsection{Biogycal Oxygen Demand (BOD)}

Nilai rata-rata BOD yang diperoleh dari masingmasing titik sampel bervariasi. Titik 1 menunjukkan nilai BOD sebesar $169,83 \mathrm{mg} / \mathrm{l}$, titik 2 sebesar 92,34 mg/l, titik 3 sebesar 143,24 mg/l, titik 4 sebesar $62,38 \mathrm{mg} / \mathrm{l}$, titik 5 sebesar 37,14 mg/l, dan titik 6 sebesar 73,02 mg/l (Gambar 5). Berdasarkan Peraturan Gubernur Provinsi Bali No. 16 Tahun 2016, baku mutu air limbah bagi usaha dan/atau kegiatan domestik kadar paling tinggi BOD adalah $100 \mathrm{mg} / \mathrm{l}$. Hasil tersebut menunjukkan bahwa BOD dititik awal masih melebihi ambang batas baku mutu, namun setelah proses berlangsung BOD sesuai dengan baku mutu hanya saja mengalami peningkatan pada titik akhir. Sedangkan berdasarkan baku mutu air laut untuk biota laut, BOD diperairan diperuntukkan sebesar $20 \mathrm{mg} / \mathrm{l}$. kondisi tersebut menunjukkan bahwa nilai BOD apabila masuk ke badan perairan masih melewati baku mutu yang telah ditetapkan.

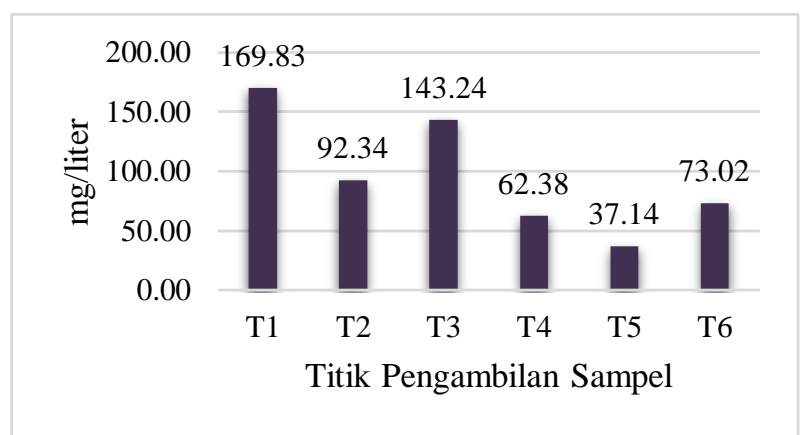

Gambar 5. Nilai Rata-Rata BOD di Tiap Titik Sampel

\subsubsection{Padatan Tersuspensi Total (TSS)}

Hasil penelitian menunjukkan kandungan TSS di tiap sampel bervariasi. Pada titik 1 TSS sebesar 93 $\mathrm{mg} / \mathrm{l}$, titik 2 sebesar 112, $18 \mathrm{mg} /$ liter, titik 3 sebesar
$105,50 \mathrm{mg} / \mathrm{l}$, titik 4 sebesar $93,52 \mathrm{mg} / \mathrm{l}$, titik 5 sebesar $86,1 \mathrm{mg} / \mathrm{l}$, dan titik 6 sebesar $68,40 \mathrm{mg} / \mathrm{l}$. Dari data pada gambar 6 kondisi TSS pada di kolam sedimentasi dan kanal effluent terjadi penurunan. Berdasarkan baku mutu air limbah bagi usaha dan/atau kegiatan domestikdan air laut untuk biota laut menunjukkan bahwa TSS masih dalam ambang batas baku mutu.

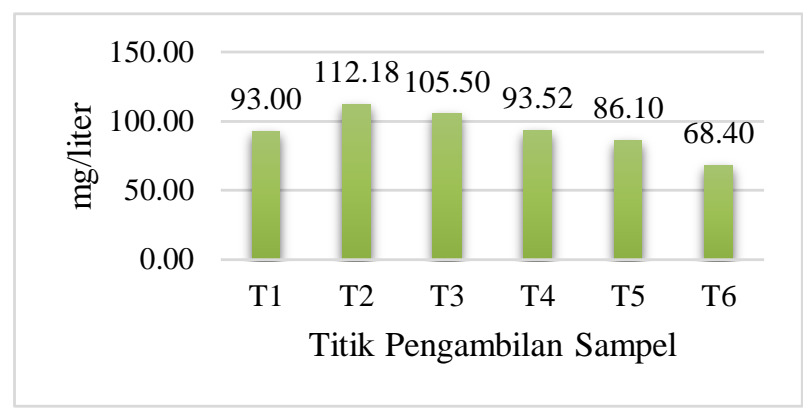

Gambar 6. Nilai Rata-Rata TSS di Tiap Titik Sampel

\subsubsection{Minyak dan Lemak}

Hasil penelitian di IPAL menunjukkan kadar minyak lemak bervariasi. Pada titik 1 kandungan minyak dan lemak sebesar $0,65 \mathrm{mg} / \mathrm{l}$, namun pada titik 2 dan 3 (kolam aerasi 1 dan 2) mengalami peningkatan yang cukup tinggi yaitu 1,73 dan 4,07. Sedangkan pada titik 4 dan 5 (kolam sedimentasi 1 dan 2) terjadi peningkatan yang cukup tinggi pada kolam sedimentasi 1 sebesar 4,17 mg/l dan 4,73 $\mathrm{mg} / \mathrm{l}$ pada kolam sedimentasi 2, dan ketika di titik 6 (kanal effluent) turun drastis hingga $0.07 \mathrm{mg} / \mathrm{l}$. Hasil tersebut menunjukkan bahwa minyak dan lemak masih sesuai dengan baku mutu (Gambar 7).

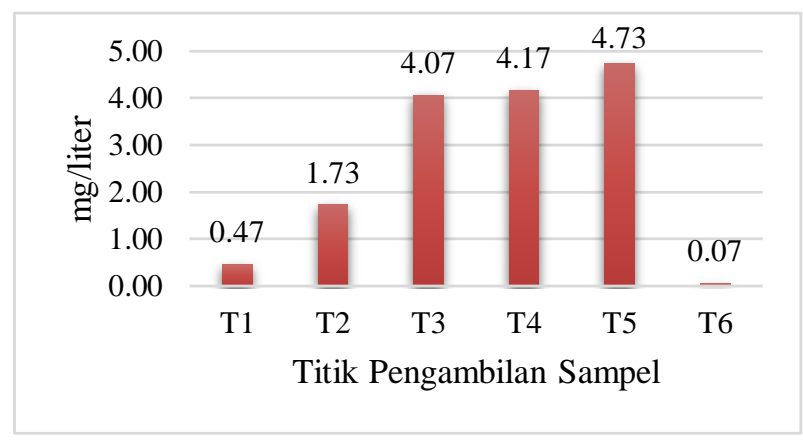

Gambar 7. Nilai Rata-Rata Minyak dan Lemak di Tiap Titik Sampel

\subsubsection{Amoniak}

Berdasarkan Peraturan Gubernur Provinsi Bali No. 16 Tahun 2016 baku mutu air laut untuk biota laut, 
kadar amoniak yang baik bagi perairan adalah 0,03 mg/l. Hasil kandungan amoniak di IPAL SuwungDenpasar menunjukkan nilai yang fluktuatif (Gambar 8). Hal ini menunjukkan bahwa kandungan amoniak sudah melebih ambang batas yang sudah ditentukan dan sangat berbahaya bagi biota laut apabila amoniak yang masuk ke dalam badan perairan dalam jumlah yang besar.

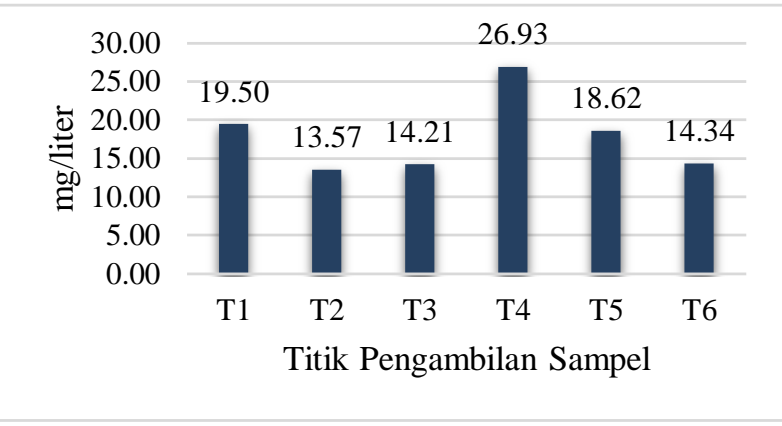

Gambar 8. Nilai Rata-Rata Amoniak di Tiap Titik Sampel

\subsubsection{Deterjen}

Berdasarkan Peraturan Gubernur Provinsi Bali No. 16 Tahun 2016 baku mutu air laut untuk biota laut, kadar deterjen yang baik bagi perairan adalah 1 $\mathrm{mg} / \mathrm{l}$. Rata-rata hasil perhitungan konsetrasi deterjen menunjukkan bahwa masih berada dibawah ambang batas (Gambar 9).

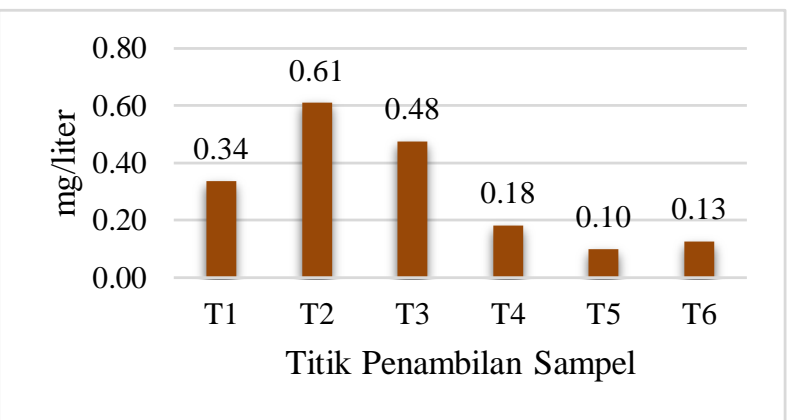

Gambar 9. Nilai Rata-Rata Deterjen di Tiap Titik Sampel

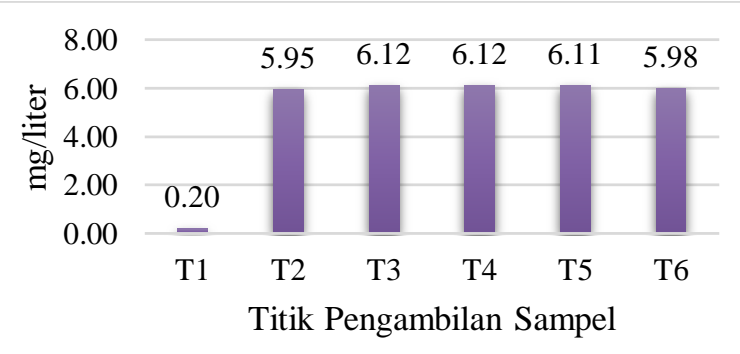

Gambar 10. Nilai Rata-Rata $\mathrm{H}_{2} \mathrm{~S}$ di Tiap Titik Sampel

\subsubsection{Hidrogen Sulfida $\left(\mathrm{H}_{2} \mathrm{~S}\right)$}

Berdasarkan Peraturan Gubernur Provinsi Bali No. 16 Tahun 2016 baku mutu air laut untuk biota laut, kadar $\mathrm{H}_{2} \mathrm{~S}$ yang baik bagi perairan adalah 0,01 mg/l. Pada Gambar 10 menunjukkan grafik konsentrasi $\mathrm{H}_{2} \mathrm{~S}$ di IPAL Suwung masih berada sangat jauh diatas ambang batas baku mutu.

\subsection{Beban Pencemaran Air Limbah}

Berdasarkan data yang diperoleh dari IPAL, debit influent IPAL rata-rata 26.783,09 $\mathrm{m}^{3}$ /hari dengan debit minimum 18.824,70 $\mathrm{m}^{3} /$ hari dan maksimum 40.034,12 m³/hari pada bulan Maret dan April 2017. Pada tabel 5 menunjukkan bahwa beban pencemaran BOD sebesar 1.955.701,23 kg/hari, TSS sebesar 1.831.963,36 kg/hari, minyak dan lemak sebesar 1.339,15 kg/hari, amoniak sebesar $384.069,51 \mathrm{~kg} / \mathrm{hari}$, deterjen sebesar 3.481,80 $\mathrm{kg} /$ hari, dan $\mathrm{H}_{2} \mathrm{~S}$ sebesar 477.810,33 kg/hari.

Tabel 5

Beban Pencemaran Air Limbah IPAL

\begin{tabular}{lccc}
\hline Parameter & $\begin{array}{c}\text { Konsentrasi } \\
\text { rata-rata } \\
\text { (mg/l) }\end{array}$ & $\begin{array}{c}\text { Debit } \\
\text { rata-rata } \\
\left.\mathbf{( m}^{3} / \mathbf{d e t}\right)\end{array}$ & $\begin{array}{c}\text { Beban } \\
\text { (kg/hari) }\end{array}$ \\
\hline BOD & 73,02 & $26.783,09$ & $1.955 .701,23$ \\
TSS & 68,40 & $26.783,09$ & $1.831 .963,36$ \\
$\begin{array}{l}\text { Minyak } \\
\text { dan Lemak }\end{array}$ & 0,05 & $26.783,09$ & $1.339,15$ \\
Amoniak & 14,34 & $26.783,09$ & $384.069,51$ \\
$\begin{array}{l}\text { Deterjen } \\
\text { Hidrogen }\end{array}$ & 0,13 & $26.783,09$ & $3.481,80$ \\
Sulfida & 17,84 & $26.783,09$ & $477.810,33$ \\
\hline
\end{tabular}

\section{Pembahasan}

Proses pengolahan air limbah yang berlangsung di IPAL pada umumnya sudah baik karena merupakan sistem off-site yang baik diterapkan pada daerah dengan kepadatan penduduk tinggi, sehingga jaringan perpipaan IPAL SuwungDenpasar sudah mencakup daerah tersebut meliputi Denpasar, Sanur dan Kuta yang merupakan pusat kota dan destinasi wisata terkenal skala internasional. Menurut hasil peramalan jumlah penduduk dan volume air limbah pada daerah layanan, jumlah volume air limbah yang dihasilkan per hari dalam setahun mengalami peningkatan 1,86\% (Nadiasa, 2011). Data yang diperoleh dari IPAL menunjukkan debit 
influent yang masuk maksimum rata-rata 40.034,12 $\mathrm{m}^{3} /$ hari mendekati debit yang diramalkan pada tahun 2017 yaitu 49.049,19 $\mathrm{m}^{3} /$ hari. Sementara kapasitas maksimum yang dapat diolah oleh IPAL pada tahap I adalah sebesar $51.000 \mathrm{~m}^{3} /$ hari.

Tingginya debit influent limbah juga dapat mengakibatkan kurang optimalnya pengolahan dari parameter limbah. Waktu tinggal optimal air limbah IPAL Suwung pada kolam aerasi adalah selama 5 hari dan pada kolam sedimentasi 40 jam (Sulihiningtyas dkk., 2010). Sedangkan waktu tinggal air limbah dengan debit influent yang tinggi, kurang lebih 1-2 hari pada kolam aerasi dan 16 jam pada kolam sedimentasi. Hal tersebut yang memacu rendahnya efektivitas pengolahan air limbah domestik IPAL.

Selain itu penyebab lemahnya sistem pengolahan di IPAL karena jaringan perpipaan yang mengalirkan limbah ke IPAL menggunakan separated system yang memisahkan aliran air limbah pada sistem sewerage dan aliran air hujan pada sistem drainase yang letaknya berdampingan sehingga air hujan tidak akan tercampur dengan air limbah. Namun sering kali terjadi penyumbatan di dalam jaringan perpipaan karena sering ditemukan padatan lemak dan sampah. Sampah tersebut akhirnya dapat menghambat proses pengolahan limbah di IPAL.

Pada bar screen yang berfungsi sebagai penangkap padatan kasar pada air buangan masih belum berjalan efektif karena padatan kasar masih dapat masuk ke proses berikutnya yang disebabkan oleh jarak bukaan antar batang berjarak $2 \mathrm{~cm}$ dengan batang yang berukuran $1 \mathrm{~cm}$. Sedangkan menurut Qasim (1985), desain kriteria desain bar screen jarak bukaan antar batang sebesar 25 - $75 \mathrm{~mm}$, lebar penampang batang 1,0 10,1 mm. Sampah tersebut berlangsung sampai ke kanal effluent karena tidak terdapat jaring sampah di tiap proses. Selain itu sampah juga dapat menghambat kinerja dari aerator sehingga aerator bekerja melebihi batas dan akhirnya konslet. Banyaknya aerator yang rusak dan terhambat juga berdampak kualitas air lainnya.

Proses pengolahan parameter seperti suhu, $\mathrm{pH}$ BOD, TSS, minyak lemak, dan deterjen pada IPAL berjalan secara efektif. Suhu pada air limbah IPAL masih sesuai baku mutu dan tergolong tinggi dibandingkan suhu air normal karena kadar oksigen terlarut dalam limbah lebih rendah dari pada kadar oksigen terlarut pada air normal. Selain itu kolam-kolam pada IPAL terkena sinar matahari secara langsung tanpa ada penutup, sehingga air limbah menjadi lebih panas dan suhunya naik. Kenaikan suhu juga dapat disebabkan oleh rendahnya oksigen terlarut yang terdapat pada air limbah, hal ini didukung oleh Pratiwi dan Ernawati (2016) yang menyatakan bahwa semakin tinggi suhu perairan maka akan berbanding terbalik dengan kadar oksigen terarut (DO) pada perairan. Sedangkan derajat keasaman $(\mathrm{pH})$ masih pada kisaran $\mathrm{pH}$ normal yaitu 7 karena beberapa gas yang mengakibatkan air menjadi asam seperti hidrogen sulfida di netralisir dengan kandungan deterjen yang bersifat basa pada limbah. Hal tersebut didukung dengan penelitian Sari dkk., (2015) yang menyatakan adanya sisa bahan deterjen, shampoo, sabun dan pembersih lainnya yang bersifat alkalis dalam air limbah mengakibatkan $\mathrm{pH}$ limbah yang rendah rendah menjadi pH netral kembali.

Tingginya kadar BOD pada air limbah karena kandungan zat-zat organik dalam limbah tinggi sehingga semakin banyak oksigen yang dibutuhkan untuk mendegradasi zat-zat organik tersebut. Efektivitas pengolahan BOD terjadi karena proses dekomposisi bahan organik (substrat) yang terkandung dalam air limbah domestik berlangsung secara terus menerus baik dari proses aerobik maupun anaerobik (Romayanto dkk., 2006). Efektivitas pengolahan TSS berdasarkan pengendapan yang terjadi pada kolam sedimentasi merupakan tipe pengendapan flocculation free settling dimana terjadi pengendapan flokulan yang terkumpul selama proses pengendapan sehingga terjadi perubahan ukuran dan bentuk. Namun pada titik 2 dan 3 terjadi peningkatan karena sedikit padatan yang mengendap secara gravitasi, sedangkan pada kolam sedimentasi dan effluent. Menurut Devi dkk. (2013) penurunan TSS paling siginifikan setelah melewati pengolahan secara filtrasi biologi. Hal tersebut juga didukung jumlah dan aktivitas masa sel mikroba yang dipengaruhi oleh bahan organik pada kolam sedimentasi. Semakin banyak bahan organik yang terurai oleh aktivitas mikroba maka kualitas limbah domestik semakin baik (Romayanto dkk., 2006).

Penurunan kadar minyak dan lemak pada effluent terjadi karena terdapat grease trap hulu perpipaan atau dari rumah-rumah maupun hotel yang mebawa limbah ke IPAL. Selain itu juga 
karena bakteri aerobik memanfaatkan minyak dan lemak sebagai substrat di IPAL. Namun terjadi peningkatan pada titik 1-5 yang disebabkan tidak adanya pengolahan khusus minyak dan lemak dalam tiap proses, sehingga kandungan minyak dan lemak terkumpul dari proses awal hingga ke kolam sedimentasi. Akan tetapi terjadi penurunan sangat drastis pada titik 6 karena minyak dapat hilang oleh adanya busa-busa yang terdapat pada effluent. Hal ini dudukung oleh Naibaho (1996) dalam Maufilda (2015) yang menyatakan minyak dapat dihilangkan saat proses netralisasi dengan penambahan $\mathrm{NaOH}$ dan membentuk sabun berbusa (scum) yang sering mengapung di permukaan dan bercampur dengan benda-benda lain pada permukaan limbah. Pada saat penelitian di dapati keberadaan busa-busa yang melimpah karena adanya tumbukan surfaktan (deterjen) yang dapat menimbulkan buih yang mengakibatkan berkurangnya kadar deterjen yang larut dalam air limbah pada effluent.

Efektifnya beberapa parameter tersebut juga disebabkan karena pengaruh aerator pada kolam aerasi dan kolam sedimentasi. Sistem aerasi tersebut dapat memenuhi dua fungsi secara bersamaan, yaitu pengadukan air limbah dengan benar dalam upaya menjaga solid tersuspensi dan terbentuknya sistem homogen, serta memberikan oksigen yang dibutuhkan. Menurut Asmadi dan Suharno (2012), aerator tersebut selain sebagai suplai oksigen ke dalam air limbah juga sebagai pembuangan karbon dioksida, pembuangan hidrogen sulfida untuk menghapuskan bau dan rasa, serta pembuangan minyak yang mudah menguap.

Sedangkan parameter lainnya seperti DO, amoniak, dan hidrogen sulfida $\left(\mathrm{H}_{2} \mathrm{~S}\right)$ memiliki beban pencemar yang tidak sesuai dengan baku mutu. Kandungan amoniak rata-rata sangat tinggi diatas baku mutu $0,3 \mathrm{mg} / \mathrm{L}$, namun pada titik 4 merupakan titik kandungan amoniak yang tertinggi dalam proses pengolahan air limbah di IPAL hal tersebut berkaitan dengan tingginya suhu pada titik 4 itu pula. Menurut Sihaloho (2009), amoniak dalam air limbah memiliki hubungan dengan pengaruh $\mathrm{pH}$ dan suhu, semakin tinggi $\mathrm{pH}$ dan suhu air limbah maka amoniak berada dalam bentuk amoniak bebas yang artinya air limbah tersebut makin beracun (toksik). Menurut Widayat dkk., (2010), apabila kandungan amoniak melebihi dari $1 \mathrm{mg} / \mathrm{L}$ akan sangat membahayakan kehidupan biota perairan beberapa jenis ikan kan mati lemas karena amoniak dapat mengurangi konsentrasi oksigen dalam air. Oleh karena itu, perlu adanya pengolahan pada IPAL untuk mengolah amoniak yang telah melebihi baku mutu apabila masuk ke badan perairan. Menurut Hibban dkk., (2016), perlu adanya suatu pengolahan lebih lanjut sebelum dibuang ke badan air baik secara fisik/kimiawi, biologis, maupun gabungan keduanya.

Kandungan oksigen terlarut yang rendah pada IPAL antara 0,87-2,83 mg/L tergolong pada kondisi perairan tercemar berat. Penyebab berkurangnya kadar oksigen terlarut dalam air limbah organik adalah degradasi dan dekomposisi yang dilakukan oleh bakteri (menggunakan oksigen dalam air), sehingga semakin lama oksigen yang terlarut dalam air akan berkurang. Hal tersebut didukung oleh Susana (2009) yang menyatakan salah satu penyebab rendahnya konsentrasi oksigen dalam perairan adalah karena berlimpahnya bahan organik. Oksigen terlarut sangat rendah pada titik 2 disebabkan karena terjadi peningkatan kandungan deterjen pada titik 2. Demikian pula sebaliknya yang terjadi pada titik 6 (effluent), terjadi peningkatan kandungan oksigen terlarut dikarenakan kandungan deterjen yang rendah. Selain itu keberadaan busa-busa di permukaan badan air menjadi salah satu penyebab kontak udara dan air terbatas sehingga menurunkan oksigen terlarut (DO) pada air limbah. Hal ini didukung oleh Yuliani dkk., (2015) yang menyatakan bahwa semakin tinggi akumulasi deterjen maka semakin rendah pula suplai oksigen terlarut dalam air. Apabila terjadi penurunan oksigen terlarut hingga nol, biota air yang membutuhkan oksigen (aerobik) akan mati, dan digantikan dengan tumbuhnya mikroba anaerobik.

Mikroba tersebut akan memanfaatkan karbon dari bahan organik sehingga pada saat respirasi anaerobik terbentuk gas asam sulfida $\left(\mathrm{H}_{2} \mathrm{~S}\right)$ yang berbau busuk. Tingginya kandungan $\mathrm{H}_{2} \mathrm{~S}$ di perairan dapat terionisasi dengan kandungan oksigen terlarut (DO) sehingga sifat toksiknya berkurang. Namun kandungan DO masih sangat rendah sehingga belum mampu mendegradasi kandungan $\mathrm{H}_{2} \mathrm{~S}$ pada air limbah. Pada titik 1 kandungan $\mathrm{H}_{2} \mathrm{~S}$ sangat rendah, namun pada titik 2-6 kandungan $\mathrm{H}_{2} \mathrm{~S}$ meningkat dan konstan, hal tersebut karena pada influent (receiving tank) ketinggian permukan air sangat rendah dibandingkan dengan beberapa proses lainnya, sehingga $\mathrm{H}_{2} \mathrm{~S}$ lebih banyak diudara dan berbau 
busuk. Sedangkan air limbah pada proses lainnya sejajar dengan permukaan sehingga, massa $\mathrm{H}_{2} \mathrm{~S}$ lebih banyak terkandung dalam air. Hal ini didukung oleh Sianipar (2009) yang menyatakan $\mathrm{H}_{2} \mathrm{~S}$ memiliki berat jenis lebih berat dibandingkan udara, sehingga sering terkumpul pada lapisan bawah dan sering terdapat pada air permukaan dan dapat sedikit larut dalam air.

Proses pengolahan IPAL yang efektif merupakan dimensi pembangunan berkelanjutan yang telah disepakati oleh 193 negara sebagai Sustainable Development Goals dengan tujuan menjamin akses atas air dan sanitasi untuk semua, serta perlindungan dan penggunaan samudera, laut dan sumberdaya kelautan secara berkelanjutan pada tahun 2030 (UN, 2016). Berdasarkan Peraturan Gubernur Provinsi Bali No. 16 Tahun 2016 proses pengolahan limbah pada IPAL Suwung-Denpasar secara keseluruhan sudah berjalan efektif sesuai dengan baku mutu air limbah bagi usaha dan/atau kegiatan domestik. Akan tetapi apabila dibandingkan dengan baku mutu air laut untuk biota laut masih belum mencapai tujuan karena hasil buangan air limbah yang masih belum efektif akan berdampak buruk bagi ekosistem mangrove sebagai ekosistem penerima. Hal tersebut akan memengaruhi biota seperti ikan yang kekurangan oksigen untuk tumbuh dan berkembang hingga menyebabkan kematian di perairan.

Namun kondisi kawasan mangrove sekitar IPAL masih belum terdampak dari adanya hasil buangan limbah kecuali kesehatan dan estetika lingkungan sekitar kawasan IPAL karena pengaruh dari busa dan bau busuk yang berasal dari hasil buangan limbah. Menurut Hartati dan Hurudu (2016), pembuangan limbah cair (sewage) pada ekosistem mangrove mengakibatkan penurunan oksigen terlarut dalam air, bahkan terjadi keadaan anoksik dalam air sehingga bahan organik dalam limbah cair akan mengalami dekomposis anaerobik yang menghasilkan hidrogen sulfida dan amoniak yang merupakan racun bagi organisme hewani dalam air. Sedangkan apabila terjadi pencemaran minyak dan pengendapan sedimen yang berlebihan akan mematikan pohon-pohon mangrove tersebut akibat dari terlapisnya pneumatofora oleh lapisan minyak dan juga sedimen. Dengan semakin banyaknya zat organik yang dibuang ke lingkungan perairan, maka perairan tersebut akan semakin tercemar yang ditandai dengan bau yang menyengat, maupun minyak dan lemak, serta deterjen yang menyebabkan penumpukan busa yang banyak sehingga akan mengurangi estetika lingkungan.

\section{Simpulan}

Proses air limbah domestik pada IPAL SuwungDenpasar efektif dalam perbaikan minyak dan lemak sebanyak $85 \%$, deterjen sebanyak $62 \%$, dan BOD sebanyak $57 \%$, sedangkan tidak efektif dalam perubahan kadar amoniak karena hanya berkurang $26 \%$, DO, dan hidrogen sulfida yang tidak sesuai dengan baku mutu lingkungan.

\section{Daftar Pustaka}

Asmadi, \& Soeharno. (2012). Dasar-Dasar Teknologi Pengolahan Air Limbah. Pontianak: Gosyen Publishing.

Avianda, S. J. (2014). Evaluasi Sistem Maintenance Jaringan Perpipaan di Denpasar Sewerage Development Project $(D S D P)$, Bali. Laporan Kerja Praktik. Bandung, Indonesia: Program Studi Teknik Lingkungan, Fakultas Teknik Sipil dan Lingkungan Institut Teknologi Bandung.

BLUPAL. (2007). Sinergi DSDP dan BLUPAL dalam Sistem Pengelolaan Air Limbah Bali, Departemen Pekerjaan Umum, Bali. Denpasar, Indonesia: Badan Layanan Umum Pengolahan Air Limbah.

BPS Provinsi Bali. (2016). Kepadatan Penduduk Per Kabupaten/Kota di Provinsi Bali Tahun 2012-2015. Denpasar, Indonesia: Badan Pusat Statistik Provinsi Bali

Cordova, M. R. (2008). Kajian Air Limbah Domestik di Perumnas Bantar Kemang, Kota Bogor dan Pengaruhnya pada Sungai Ciliwung. Skripsi. Bogor, Indonesia: Fakultas Perikanan dan Ilmu Kelautan, Institut Pertanian Bogor.

Devi, L. P. W. K., Putra, K. G. D., \& Putra A. A. B. (2013). Efektifitas Pengolahan Air Effluent Menjadi Air Reklamasi Di Instalasi Pengolahan Air Limbah Suwung Denpasar Ditinjau Dari Kandungan Kekeruhan, Total zat Terlarut (TDS), dan Total zat Tersuspensi (TSS). Jurnal Kimia, 7(1), 64-74.

Ginting, P. (2007). Sistem Pengelolaan Lingkungan dan Limbah Industri, Cetakan Pertama. Bandung, Indonesia: Yrama Widya.

Hartati, \& Harudu L. (2016). Identifikasi Jenis-jenis Kerusakan Ekosistem Hutan Mangrove Akibat Aktivitas Manusia di Kelurahan Lowu-Lowu Kecamatan Lea-Lea Kota Baubau. Jurnal Penelitian Pendidikan Geografi, 1(1), 30-45.

Hibban, M., Rezagama A., \& Purwono. (2016). Studi Penurunan Konsentrasi Amonia dalam Limbah Cair Domestik dengan Teknologi Biofilter Aerobmedia 
Tubular Plastik pada Awal Pengolahan. Jurnal Teknik Lingkungan, 5(2), 1-9.

Maufilda, D. (2015). Kandungan BOD, COD, TSS, pH, dan Minyak atau Lemak Pada Air Limbah di Inlet dan Outlet Industri Cold Storage Udang (Studi di PT. Panca Mitra Multi Perdana Kapongan-Situbondo). Skripsi. Jember, Indonesia: Fakultas Kesehatan Masyarakat, Universitas Jember.

MNLH. (2014). Keputusan Menteri Negara Lingkungan Hidup Nomor 5 Tahun 2014 tentang Baku Mutu Air Limbah. Jakarta, Indonesia: Menteri Negara Lingkungan Hidup.

Nadiasa M. (2011). Kapasitas Jenuh Instalasi Pengolahan Air Limbah Denpasar Sewerage Development Project (DSDP). Jurnal Ilmiah Teknik Sipil, 15(2), 123-130.

Pratiwi, M. A., \& Ernawati, N. M. (2016). Analisa Kualitas Air dan Kepadatan Moluska pada Kawasan Ekosistem Mangeove, Nusa Lembongan. Journal Marine and Aquatic Sciences, 2(2), 67-72.

Qasim, S. R. (1985). Wastewater Treatment Plant (Planning, Design, and Operation). New York, USA: CBS College Publishing.

Romayanto, M. E. W., Wiryanto, \& Sajidan. (2006). Pengolahan Limbah Domestik Dengan Aerasi dan Penambahan Bakteri Pseudomonas putida. Bioteknologi, 3(2), 42-49.

Sari, N. R., Sunarto, \& Wiryanto. (2015). Analisis Komparasi Kualitas Air Limbah Domestik Berdasarkan Parameter Biologi, Fisika, dan Kimia di IPAL Semanggi dan IPAL Mojosongo Surakarta. Jurnal Ekosains, 7(2), 62-74.

Sianipar, R. H. (2009). Analisa Risiko Paparan Hidrogen Sulfida Pada Masyarakat Sekitar TPA Sampah Terjun Kecamatan Medan Marelan Tahun 2009. Tesis. Medan,
Indonesia: Sekolah Pascasarjana, Universitas Sumatera Utara.

Sihaloho, W. S. (2009). Analisa Kandungan Amonia Dari Limbah Cair Inlet Dan Outlet Dari Beberapa Industri Kelapa Sawit. Karya Ilmiah. Medan, Indonesia: Program Studi Diploma-3 Kimia Analisis, Fakultas Matematika dan Ilmu Pengetahuan Alam Universitas Sumatera Utara.

Soeparman, \& Suparmin (2001). Pembuangan Tinja dan Limbah Cair. Jakarta: Buku Kedokteran EGC.

Sulihiningtyas, W. D., Suyasa, I. W. B., \& Wahyuni, N. M I. (2010). Efektivitas Sistem Pengolahan Instalasi Pengolahan Air Limbah Suwung Denpasar terhadap Kadar BOD, COD, dan Amonia. Jurnal Kimia, 4(2), 141-148.

Susana, T. (2009). Tingkat Keasaman (pH) dan Oksigen Terlarut Sebagai Indikator Kualitas Perairan Sekitar Muara Sungai Cisadane. Jurnal Teknologi Lingkungan, 5(2), 33-39.

UN. (2016). The Sustainable Development Goals Report. New York, USA: United Nations

Widayat, W., Suprihatin, \& Herlambang A. (2010). Penyisihan Amoniak Dalam Upaya Meningkatkan Kualitas Air Baku PDAM-IPA Bojong Renged Dengan Proses Biofiltrasi Menggunakan Media Plastik Tipe Sarang Tawon. Jurnal Air Indonesia, 6(1), 64-76.

Yuliani, R. L., Purwanti, E., \& Pantiwati, Y. (2015). Pengaruh Limbah Detergen Industri Laundry terhadap Mortalitas dan Indeks Fisiologi Ikan Nila (Oreochromis niloticus). Dalam Prosiding Seminar Nasional XII Pendidikan Biologi FKIP UNS 2015 (SEMBIO). Surakarta, Indonesia, 8 Agustus 2015 (pp. 822-828).

(C) 2018 by the authors; licensee Udayana University, Indonesia. This article is an open access article distributed under the terms and conditions of the Creative Commons Attribution license (http://creativecommons.org/licenses/by/3.0/). 